\title{
Opportunities and Challenges in Applying Distributed Ledger Technologies in Global Supply Chains for Social Good
}

\author{
Catherine Thompson* \\ Fairtrade Foundation, London, United Kingdom
}

Keywords: Fairtrade, blockchain, supply chain, oxchain, products, distributed ledger technologies, DLTs, tech for good

\section{INTRODUCTION}

Fairtrade is a global movement with a strong and active presence in the UK, represented by The Fairtrade Foundation. Fairtrade is a movement for change that works directly with businesses, consumers, and campaigners to make trade deliver for farmers and workers. The international Fairtrade system (which the Fairtrade Foundation is a part of) represents the world's largest and most recognised fair trade system (Fairtrade Foundation, 2019b).

In 2016, there were 1,411 Fairtrade certified producer organisations worldwide, representing

OPEN ACCESS

Edited by:

Kate Symons,

University of Edinburgh

United Kingdom

Reviewed by:

Richard Tighe,

Oxfam, United Kingdom

*Correspondence:

Catherine Thompson media@fairtrade.org.uk

Specialty section:

This article was submitted to Blockchain for Good,

a section of the journal

Frontiers in Blockchain

Received: 30 April 2019

Accepted: 26 August 2019

Published: 06 September 2019

Citation:

Thompson C (2019) Opportunities and Challenges in Applying Distributed Ledger Technologies in Global Supply

Chains for Social Good.

Front. Blockchain 2:11.

doi: 10.3389/fbloc.2019.00011 over 1.6 million farmers and workers. Fairtrade have standards that cover supply chains of over 350 products, however in 2016 the products that generated most Fairtrade Premium were coffee, bananas, cocoa, cane sugar, flowers and plants, tea, cotton and wine. Fairtrade's vision is a world in which all producers can enjoy secure and sustainable livelihoods, fulfil their potential and decide on their future (Fairtrade International, 2018).

There have been a number of applications for Distributed Ledger Technologies (DLTs), also known as blockchain technologies, which are being discussed and explored for use in global supply chains (Marr, 2018). Some examples of the applications that Fairtrade have come across include use of distributed ledger technologies in geographic supply chain tracking, for example in food fraud and safety, supply chain data sharing, physical traceability tracking, proof of provenance, waste and efficiency monitoring and in supply chain finance using applications that look at proof of ownership, and ownership transfer and automating payments in relation to this.

This opinion piece explores of the opportunities and challenges of applying distributed ledger technologies for social good within global supply chains based on publically published information over the last 3 years. It focuses on potential opportunities and challenges from features of the application of DLTs of distribution, transparency \& immutability, and automation.

\section{POTENTIAL OPPORTUNITIES AND CHALLENGES RELATING TO FEATURES OF DISTRIBUTED LEDGER TECHNOLOGIES (DLTS) WITHIN GLOBAL SUPPLY CHAINS}

\section{Distribution}

A key feature of DLTs is distribution, that is, the ability to store indistinguishable copies of all information independently validated without the need of a central authority. This ability removes the need for a central point of trust, enabling the creation of decentralised systems (Deloitte Touche Tohmatsu India LLP, 2017). 


\section{Potential Opportunities of Distribution}

In supply chains, worldwide, billions of dollars are lost due to different kinds of corruption and fraud including bribery, misappropriation of property and/or information, embezzlement, money laundering, and obstruction of justice (United Nations Global Compact, 2013). If a truly decentralised system can be designed, DLTs have the potential to significantly reduce the risk of corruption through the removal of central authorities vulnerable to corruption.

\section{Potential Challenges of Distribution}

By its definition, distribution requires information to be stored multiple times. All the resources used to store information is multiplied by the number of times that information is stored-making permissionless DLTs at this time highly energy inefficient with significant implications for both financial and environmental sustainability of any application of DLTs (de Vries, 2018).

In many supply chains that Fairtrade work in, farmers live in poverty. In Cote D'Ivoire, a typical cocoa farmer lives on $<\$ 1$ a day, whereas $\$ 2.50$ is the amount they need to earn each day in order to achieve a living income (Fairtrade Foundation, 2019a). If there are additional financial costs to implement DLTs in a supply chain, any potential implications for farmers or workers in relation to income need to be considered and balanced against benefits of implementation, and ownership of data and data infrastructure.

\section{Transparency and Immutability}

Transparency and Immutability are key features in relation to the potential of blockchain technologies (Galen et al., 2018). Galen et al. (2018) define transparency as "anyone with access to the network can view a history of transactions in real time" and immutability as "no one entity is able to change past data without alerting the network." These are features of DLTs-but encryption can be used to limit the visibility of data involved in transactions, and in permissioned networks, those with access to the network can be restricted (Androulaki et al., 2018).

\section{Potential Opportunities of Transparency and Immutability}

The combination of transparency and immutability of transactions enables for trust to be established (Galen et al., 2018). Many agricultural producer organisations worldwide need to provide information to a wide range of different actors. Multiple certification is one example of this. In 2015, 21\% of certified cocoa area was covered by more than one ISEAL member certification (ISEAL Alliance, 2018a). If there were ways to share trusted data that could be controlled and managed by agricultural producer organisations, this has the potential to reduce duplication and support cost savings for producers, as well as incentivising and supporting the development of internet of things sensors and devices through unlocking financial savings or additional income (Deloitte, 2018).

\section{Potential Challenges of Transparency and Immutability}

There are many challenges relating to the implementation of DLTs together with an effective co-existence of privacy and transparency (Kritikos, 2018). If applied without this effective coexistence, there is a risk that any application of DLTs in supply chains could be contrary to data legislation as well as being at risk of contravening Article 12 of the Universal Declaration of Human Rights (United Nations, 1948), where applications of DLTs are taken from contexts where all supply chain actors are legal business entities, and applying it to a smallholder context where actors in supply chains, if not supported via a cooperative or other legal structure, can be open to significant exposure as individuals, required to share personal information due to pressure from supply chain actors upstream or potentially lose the ability to sell their produce. Within communities, there have been challenges in ensuring verification of free, prior, and informed consent in relation to the UN Declaration on the Rights of Indigenous Peoples (ISEAL Alliance, 2018b). Free and informed consent in relation to data legislation could face similar challenges.

Consumer trust is a key reason why organisations are applying DLTs (Accenture, 2016), although a key challenge in DLTs is the recognition that often the data being stored is poor quality, lacking in accuracy (Villaincourt, 2018). There is a challenge that data on DLTs will be trusted by consumers, despite challenges in quality of data being stored transparently and immutably.

It is also noted that there are significant technological challenges connecting physical and digital records of products, especially where the value of the products is low (Tucker and Catalini, 2018).

\section{Automation}

Some DLT platforms have the ability to deliver smart contracts, that is, the execution of arbitrary, programmable transaction logic (Androulaki et al., 2018). This enables DLTs to autonomously execute transactions based on a programmed set of conditions.

\section{Potential Opportunities of Automation}

Autonomy within DLTs enable a set of transactions and conditions to be linked. For example, if one transaction occurs, transferring ownership of goods, a "smart contract" could facilitate the payment for the goods to a number of parties. This has the potential to reduce the perceived financial risk of transactions, or set up additional conditions that could create value for organisations within supply chains (Deloitte, 2016). If applied carefully, this has the potential to generate financial savings within supply chains.

\section{Potential Challenges of Automation}

As noted above there is corruption and fraud in supply chains worldwide (United Nations Global Compact, 2013). With the evolution of technology, including DLTs, criminals involved in fraud will continue to seek low risk, high reward opportunities to commit fraud and cyber crime (City of London Police, 2017). Automation within DLT has the potential to develop systemic 
weaknesses such as those that are vulnerable to fraud and cyber crime.

\section{CONCLUSION}

Distributed Ledger Technologies and their application are evolving quickly; there are many opportunities and challenges in applying these technologies within global supply chains for social good. This opinion piece has outlined just a few of these emerging opportunities and challenges which should be considered in the application of these technologies.

\section{AUTHOR CONTRIBUTIONS}

The author confirms being the sole contributor of this work and has approved it for publication.

\section{REFERENCES}

Accenture (2016). Blockchain Wave Headed Toward CPG and Retail Industries. Available online at: https://www.accenture.com/gb-en/insight-highlights-cgsblockchain-cpg-and-retail-industries (accessed March 31, 2019).

Androulaki, E., Barger, A., Bortnikov, V., Cachin, C., Christidis, K., De Caro, A., et al. (2018). Hyperledger Fabric: A Distributed Operating System for Permissioned Blockchains. Available online at: https://arxiv.org/abs/1801.10228 (accessed March 31, 2019).

City of London Police (2017). National Policing Lead for Economic Crime Annual Review 2016-2017. Available online at: https://www.cityoflondon.police.uk/ advice-and-support/fraud-and-economic-crime/Documents/ecd-annualreview-201617.pdf (accessed March 31, 2019).

de Vries, A. (2018). Bitcoin's growing energy problem. Joule 2, 801-805. doi: 10.1016/j.joule.2018.04.016

Deloitte (2016). How Blockchain Can Reshape Trade Finance. Available online at: https://www2.deloitte.com/content/dam/Deloitte/global/Documents/grid/ trade-finance-placemat.pdf (accessed March 31, 2019).

Deloitte (2018). Using Smart Sensors to Drive Supply Chain Innovation. Available online at: https://www2.deloitte.com/content/dam/Deloitte/us/Documents/ process-and-operations/us-cons-smart-sensors.pdf (accessed March 31, 2019).

Deloitte Touche Tohmatsu India LLP (2017). Key Characteristics of the Blockchain. Available online at: https://www2.deloitte.com/content/dam/Deloitte/in/ Documents/industries/in-convergence-blockchain-key-characteristics-noexp. pdf (accessed March 31, 2019).

Fairtrade Foundation (2019a). Living Income Campaigner Briefing. Available online at: https://www.fairtrade.org.uk/ /media/FairtradeUK/Fairtrade\%20Fortnight \%202019/Fortnight2019_Campaigner_Briefing.pdf (accessed March 31, 2019).

Fairtrade Foundation (2019b). What is Fairtrade. Available online at: https:// www.fairtrade.org.uk/What-is-Fairtrade/Who-we-are (accessed March 31, 2019).

Fairtrade International (2018). Monitoring the Scope and Benefits of Fairtrade Monitoring Report 9th Edn. Available online at: https://www.fairtrade.net/ fileadmin/user_upload/content/FairtradeMonitoringReport_9thEdition_lores. pdf (accessed March 28, 2019).

Galen, D. J., El-Baz, B., Brand, N., Kimura, I., Boucherle, L., Wharton, K., et al. (2018). Blockchain for Social Impact. Stanford Graduate School of Business Center for Social Innovation. Available online at: https://www. gsb.stanford.edu/sites/gsb/files/publication-pdf/study-blockchain-impactmoving-beyond-hype_0.pdf (accessed March 31, 2019).

\section{FUNDING}

The Fairtrade Foundation is a registered charity, 1043886. The Fairtrade Foundation received no restricted funding to directly fund this manuscript, however currently are funded by a number of institutional grants and public donors further to commercial income from a wide range of businesses. Details of all the funding received by The Fairtrade Foundation are detailed in the annual accounts and trustee's annual report, available from the Charity Commission.

\section{ACKNOWLEDGMENTS}

Thanks go to all the farmers, workers, campaigners, supporters and businesses that are part of the Fairtrade system.

ISEAL Alliance (2018a). Enabling FPIC through Voluntary Standards. Available online at: https://www.isealalliance.org/sites/default/files/resource/2019-04/ FPIC_Exec_Summary.pdf (accessed March 31, 2019).

ISEAL Alliance (2018b). Multiple Certfication in Coffee \& Cocoa. Available online at: https://www.isealalliance.org/sites/default/files/resource/2019-02/DIPI_ Multiple_Certification_Analysis_Final_Oct\%202018.pdf (accessed March 31, 2019).

Kritikos, M. (2018). What If Blockchain offered a Way to Reconcile Privacy With transparency? Scientific Foresight Unit (STOA), European Parliament. Available online at: http://www.europarl.europa.eu/RegData/etudes/ATAG/ 2018/624254/EPRS_ATA(2018)624254_EN.pdf (accessed March 31, 2019).

Marr, B. (2018). How Blockchain Will Tranform the Supply Chain and Logistics Industry. Available online at: Forbes.com; https://www.forbes.com/sites/ bernardmarr/2018/03/23/how-blockchain-will-transform-the-supply-chainand-logistics-industry/\#54e8a3435fec (accessed March 31, 2019).

Tucker, C., and Catalini, C. (2018). What Blockchain Can't Do. Harvard Business Review. Available online at: https://hbr.org/2018/06/what-blockchain-cant-do (accessed March 31, 2019).

United Nations (1948). Universal Declaration of Human Rights. Available online at: https://www.un.org/en/universal-declaration-human-rights/ (accessed March 31, 2019).

United Nations Global Compact (2013). Stand Together Against Corruption, A Practical Guide to Help Prevent Corruption in the Supply Chain. Available online at: https://www.globalcompact.de/wAssets/docs/Korruptionspraevention/ Publikationen/stand_together_against_corruption.pdf (accessed March 31, 2019).

Villaincourt, S. (2018). Blockchain: Only as Good as its Data. Available online at: https://www.forbes.com/sites/forbestechcouncil/2018/07/17/ blockchain-only-as-good-as-its-data/\#5db091b127c2 (accessed March 31, 2019).

Conflict of Interest Statement: The author declares that the research was conducted in the absence of any commercial or financial relationships that could be construed as a potential conflict of interest.

Copyright (c) 2019 Thompson. This is an open-access article distributed under the terms of the Creative Commons Attribution License (CC BY). The use, distribution or reproduction in other forums is permitted, provided the original author(s) and the copyright owner(s) are credited and that the original publication in this journal is cited, in accordance with accepted academic practice. No use, distribution or reproduction is permitted which does not comply with these terms. 